\title{
Efficiency of Pollutant Removal from Surface Water in a Conventional Water Treatment System
}

\author{
Artur Jachimowski ${ }^{1, *}$ \\ ${ }^{1}$ Chair of Product Technology and Ecology, Faculty of Commodity Science and Product Management, Krakow University of \\ Economics, Rakowicka 27, 31-510 Kraków, Poland
}

\begin{abstract}
The article contains an assessment of efficiency of removal of impurities from surface water using the technology employed by "Raba" plant of the Municipal Water and Sewerage Company in Cracow (MPWiK). Research conducted by the laboratory staff shows that the functioning process system for water treatment makes it possible to obtain water with parameters corresponding to the currently applicable regulations on the quality of treated water at the outlet of the plant. Selected microbiological indicators during the treatment process and physicochemical parameters in raw and potable water underwent statistical analysis. In the first case, only Clostridium perfringens bacteria and coliform bacteria were analysed. The other bacteriological parameters in the water production process gave a result of $0 \mathrm{cfu} / 100 \mathrm{ml}$. In the second case, the average rates of removal of impurities were calculated in order to check the efficiency of the treatment process. In the examined water, the highest efficiency of removal of impurities was observed with regard to the following indicators: nitrates (III), turbidity, colour, ammonium ion and phosphates. The research conducted showed that the quality of treated water was affected by the degree of pollution of raw water and the use of appropriate stages of the process system which removed impurities and neutralised pathogenic microorganisms.
\end{abstract}

\section{Introduction}

In order to select the appropriate method of water treatment, first and foremost, the quantity and quality of the water drawn are to be specified. In this case, a quality assessment consists in specifying the values of microbiological and physicochemical parameters of water. Determination of water composition and changeability makes it considerably easier to design a suitable process system. Selection of a technology to enable production of water meeting the requirements of the Legislator is a prerequisite. In recent years, an increase of requirements for water intended for human consumption has been observed. This is related to an amendment of national regulations, which is the effect of Poland's accession to the European Union and adoption of Community requirements. These changes impose an increase in the efficiency of water treatment technologies in newly built plants and those already in use [1]. The engineering process of surface water treatment in the majority of water supply plants is based on the same system (Figure 1). This is subject to modifications depending on the type and magnitude of concentration of pollutants and impurities that must be removed from the water.

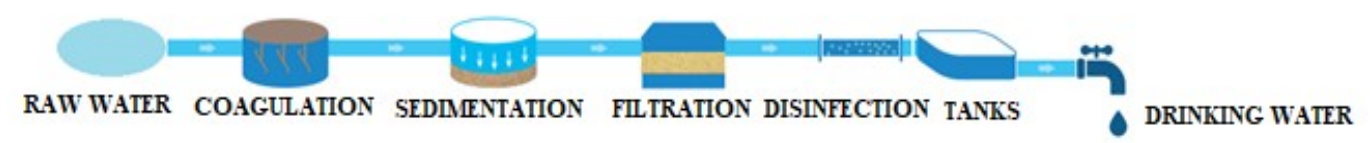

Fig.1. Process system for surface water treatment Source: own research

The purpose of the paper was to determine the efficiency of removal of pollutants from surface water using the technology employed by "Raba" plant of the Municipal Water and Sewerage Company in Cracow (MPWiK). Selected water quality indicators before and after the treatment process were being analysed from 2011 to 2017.

\footnotetext{
*Corresponding author: artur.jachimowski@uek.krakow.pl
}

\section{Description of the water treatment technology at "Raba" Water Treatment Plant}

The main production of drinking water for the city of Cracow is based on four plants differing in treatment technology: "Bielany", "Rudawa", "Dłubnia" and "Raba". Furthermore, the largest source of drinking 
water for Cracow agglomeration is a dammed reservoir on Raba River, constructed in the town of Dobczyce. Storage of water in that reservoir makes it possible to even out the volume of water drawn. Raw water is drawn from the reservoir by an intake tower. Next, water drawn from the source is pumped to "Raba" Water Treatment Plant located almost $2 \mathrm{~km}$ away, which produces drinking water in the volume of approx. $100,000 \mathrm{~m}^{3} /$ day.

The water treatment technology at "Raba" Water Treatment Plant includes ozonation, coagulation by volume, sorption on powdered activated carbon, sedimentation, filtration and disinfection using UV radiation and sodium hypochlorite (Figure 2). Preozonation of raw water takes place in a two-chamber contact tank. Next, water flows through a mixing chamber into which a coagulant is dosed, activated carbon and (periodically) lime and flocculant. Subsequently, it flows into two independently operating process lines: Raba I and Raba II. In the first one, water drawn directly from the intake is fed for the purpose of flash mixing (1st, 2nd and 3rd stage mixers). Then, it flows into vortex chambers where it undergoes coagulation. The next stage are horizontal sedimentation tanks from where water flows directly onto rapid sand filters. Water purified in such a way flows into two clean water tanks with a volume of $3,000 \mathrm{~m}^{3}$ each, where disinfection using UV radiation and sodium hypochlorite, after which it is suitable for consumption. Raba II is based on a much more modern engineering process providing water of better quality. Three devices (flash mixers, vortex chambers and sedimentation tanks) have been replaced by accelerators. In Dobczyce, there are devices in operation from which water flows directly onto sand-anthracite filters. Downstream of the filters, it flows into two clean water tanks where it is disinfected using UV radiation and sodium hypochlorite. The treated water from Raba I and Raba II tanks is pumped through two pipelines into three drinking water tanks in Gorzków with a volume of $7,500 \mathrm{~m}^{3}$ each. At a later stage, it flows gravitationally to Siercza where it can be additionally disinfected using sodium hypochlorite. Next, water flows into a flow splitting chamber of Piaski Wielkie Control House, from where it is fed into the water supply network of the city of Cracow and a few other towns $[2,3]$.

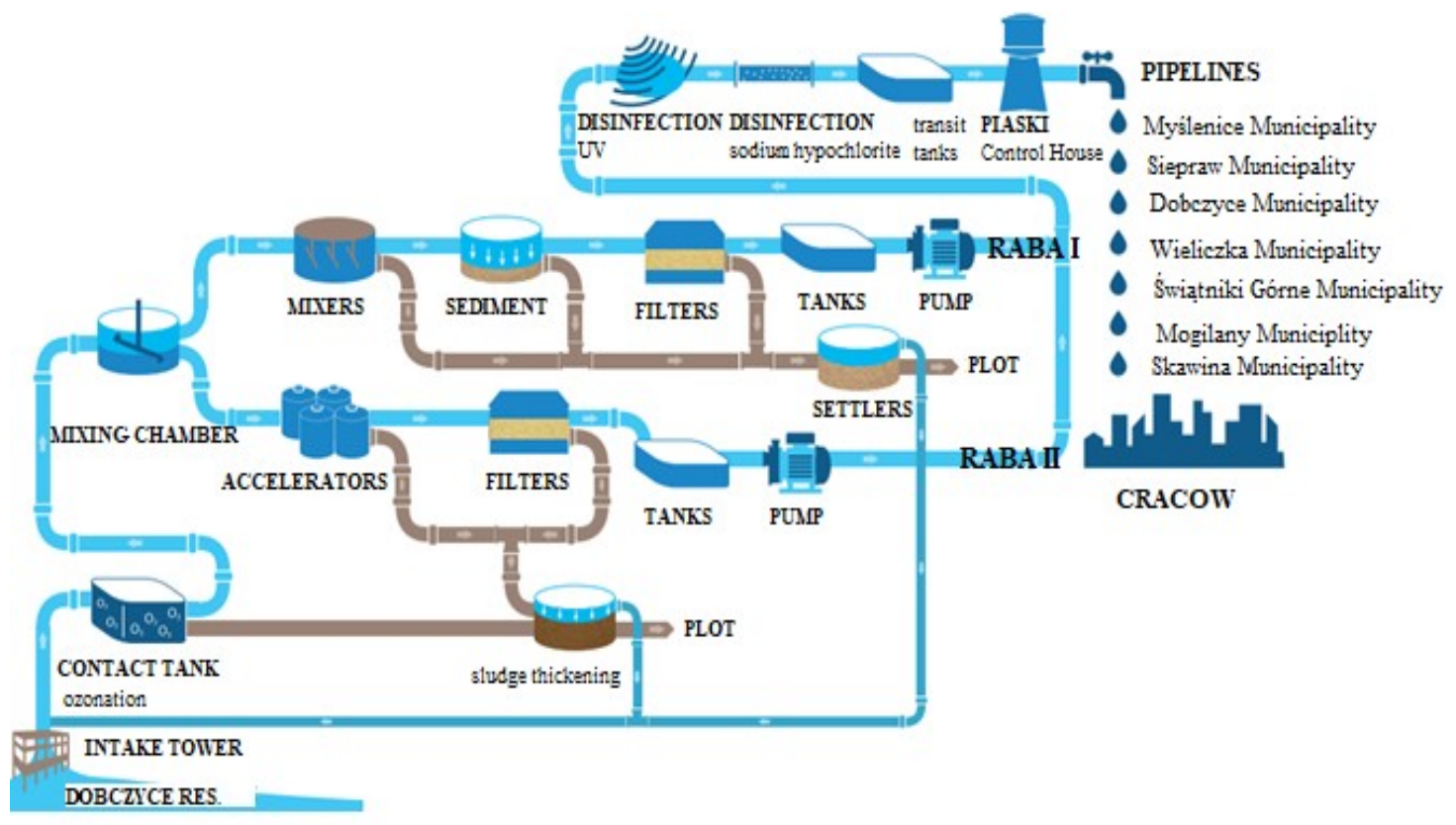

Fig. 2. Process system at "Raba" Water Treatment Plant Source: own research based on MPWiK's data

\section{Methodology}

The research subject was water drawn from "Raba" plant of the Municipal Water and Sewerage Company in Cracow before, during and after the treatment process. Laboratory analysis of raw and drinking water covered the period from 2011 to 2017. Pre-treatment water samples were being collected on a weekly basis throughout each month, whereas post-treatment water samples - on a three-day basis. During the seven-year research period, determinations of microbiological water indicators at individual stages of its purification were conducted at least twice a year. Using the obtained results, mean annual and monthly values from the sevenyear period were calculated. The results of analyses were made available by the Central Laboratory of MPWiK [4], and determinations of selected indicators were made in accordance with the register of research methods [5].

Bacteriological indicators discussed in the article were determined using the method of membrane filtration. Total hardness was examined using titration methods [6-8] and ion chromatography was employed to determine the chemical composition of the examined water. This technique enables detection and quantitative 
determination of anions found in one sample. Moreover, as far as determinations of cations are concerned, it detects cations $\left(\mathrm{Ca}^{2+}, \mathrm{Mg}^{2+}, \mathrm{Na}^{+}, \mathrm{K}^{+}\right)$and ammonium ions $\left(\mathrm{NH}_{4}^{+}\right)$[9-13].

Basic statistical parameters were calculated for selected raw water quality parameters: mean, minimum and maximum values, standard deviation. Furthermore, the efficiency of removal of pollutants was calculated from the following formula:

$$
\mathrm{E}=\left(1-\mathrm{C}_{\mathrm{o}} / \mathrm{C}_{\mathrm{s}}\right) \times 100[\%]
$$

where:

$\mathrm{C}_{\mathrm{o}}$ - concentration of the investigated indicator in treated water;

$\mathrm{C}_{\mathrm{s}}$ - concentration of the investigated indicator in raw water.

In order to identify processes shaping the chemical composition of water in 2011-2017, drawn and treated by "Raba" Water Treatment Plant, factor analysis procedure using the principal component method was employed. This technique makes it possible to analyse at the same time variability of all investigated parameters of water and isolate them in the form of factors of various sources of supply of pollutants to surface water. Another possibility is determination of the percentage share of these sources in shaping of the chemical composition of water [14]. The principal component method was also employed to compare the analysis carried out for 2007-2014 [15] and therefore only those parameters were used which had enough representation and shown variation in the examined period.

\section{Analysis and discussion of results}

\subsection{Factors shaping the chemical composition of raw water}

In the natural (geogenic) and anthropogenic pollutants can be present in water, determining its quality. Natural pollutants include: suspensions, clay particles, loams, plant debris and algae responsible for water turbidity, with humic substances affecting its colour. Among pollutants resulting from human activity, one can distinguish those depending on physical (cause the water to be turbid and have taste, smell and colour), chemical and biological properties as well as those constituting a group of compounds and substances dissolved in water.

Physicochemical parameters of raw water determined in 2011-2017 underwent component analysis: colour, turbidity, $\mathrm{pH}$, conductivity, alkalinity, total hardness as well as iron, manganese, suspensions, dissolved oxygen, $\mathrm{BOD}_{5}$, COD, total phosphorous, Kjeldahl nitrogen, ammonium ion, chlorides, nitrates (III), nitrates (V), phosphates (V), sulphates (VI) and total organic carbon indicators. What was isolated for the above parameters were the most important factors (Table 1) corresponding to anthropogenic and natural processes that shape the chemical composition of the examined water.

Similarly to the analysis carried out for the period 2007-2014 [15] for water from Dobczyce Reservoir, 4 factors were isolated, explaining $70 \%$ of the chemical composition of raw water covered by the area of research (2011-2017). Factor 1 (explaining the variability of the chemical composition in $26 \%$ ) was strongly associated with alkalinity, total hardness, conductivity and slightly less so with nitrates (III) (negative charge), whereas factor 2 ( $22 \%$ of variability of the chemical composition) determined the strength of relationship with total iron, turbidity and colour. Factor 3 , responsible for $13 \%$ of variability in the population, was correlated with $\mathrm{BOD}_{5}$ and total organic carbon (negative charge). The share of factor 4 was $10 \%$ of variability. It was characterised by sulphates (VI) and suspensions. In the case of raw water drawn by "Raba" Water Treatment Plant, determination of the impact of individual sources of pollutants on the quality of water gives rise to problems, since reduction of charges of biogenic elements occurs on some stretches of Raba River [16]. That is why the conducted factor analysis did not isolate the parameter directly responsible for supply of biogenic compounds to the reservoir [15].

Table 1. Rotated component matrix - raw water from Dobczyce Reservoir.

\begin{tabular}{|c|r|r|r|r|}
\hline \multirow{2}{*}{ Indicator } & \multicolumn{4}{|c|}{ Component } \\
\cline { 2 - 5 } & $\mathbf{1}$ & $\mathbf{2}$ & $\mathbf{3}$ & $\mathbf{4}$ \\
\hline Alkalinity & 0.891 & & & \\
\hline Total hardness & 0.853 & & & \\
\hline Conductivity & 0.795 & & & \\
\hline Nitrates (III) & -0.620 & & & \\
\hline Iron & & 0.962 & & \\
\hline Turbidity & & 0.950 & & \\
\hline Colour & & 0.623 & & \\
\hline BOD5 & & & 0.776 & \\
\hline TOC & & & -0.685 & \\
\hline Sulphates (IV) & & & & 0.724 \\
\hline Suspensions & & & & 0.636 \\
\hline $\begin{array}{c}\text { \% share in } \\
\text { variability }\end{array}$ & 26 & 22 & 13 & 10 \\
\hline
\end{tabular}

Source: own research based on MPWiK's results

\subsection{Microbiological indicators}

In 2011-2017, water from "Raba" Water Treatment Plant was assessed during the treatment process in terms of its microbiological quality. The following indicators were the subject of the analysis: coli bacteria, enterococci (faecal streptococci) and Clostridium perfringens (including its spores). Samples for laboratory tests were being collected in this case at threemonth intervals.

Clostridium perfringens and coliform bacteria were detected in the tested water (Figures 3a-3b). The other microbiological indicators in the water production process gave a result of $0 \mathrm{cfu} / 100 \mathrm{ml}$. The highest mean annual values of the total number of coliforms (445 $\mathrm{cfu} / 100 \mathrm{ml}$ ) were recorded in the samples collected in 2015 (Figure 3a). There was a rapid growth of microorganisms after sedimentation in the settling tank $205 \mathrm{cfu} / 100 \mathrm{ml}$. The remaining stages of water treatment 
showed high efficiency and the result in drinking water amounted to $0 \mathrm{cfu} / 100 \mathrm{ml}$.

There can be periodic problems in surface water treatment plants related to the neutralisation and removal of bacteria of the Clostridium genus. These bacteria can find their way through the process system of a water treatment plant (coagulation, filtration) and appear in the treated water despite the use of the disinfection process. The presence of these bacteria in the treated water is usually connected with inadequate design of the contact chambers, as a result of which the time of contact of water with chlorine is too short. If the disinfection process is conducted correctly, these bacteria will not be detected in the water supply network [17]. In the tested samples, the highest mean annual values related to Clostridium perfringens were observed in 2012, in water drawn from Dobczyce Reservoir (Figure 3b). 46 cfu/100 $\mathrm{ml}$ were detected in raw water. Subsequently, after initial ozonation in Raba II process system, $7 \mathrm{cfu} / 100 \mathrm{ml}$ were observed. Next, after passing through four accelerators, there were $7 \mathrm{cfu} / 100 \mathrm{ml}$, and the value of the indicator was the same after sedimentation tank ( $7 \mathrm{cfu} / 100 \mathrm{ml})$. In process lines Raba I (RI) and Raba II (RII), after rapid filtration on anthracite-sand beds, $0 \mathrm{cfu} / 100 \mathrm{ml}$ was recorded. The lowest values related to Clostridium perfringens occurred in water drawn on 29 July 2013. Raw water and water after ozonation (in the accelerator and sedimentation tank) had $1 \mathrm{cfu} / 100 \mathrm{ml}$ that day, whereas downstream of R I and R II rapid filters, the result was $0 \mathrm{cfu} / 100 \mathrm{ml}$.

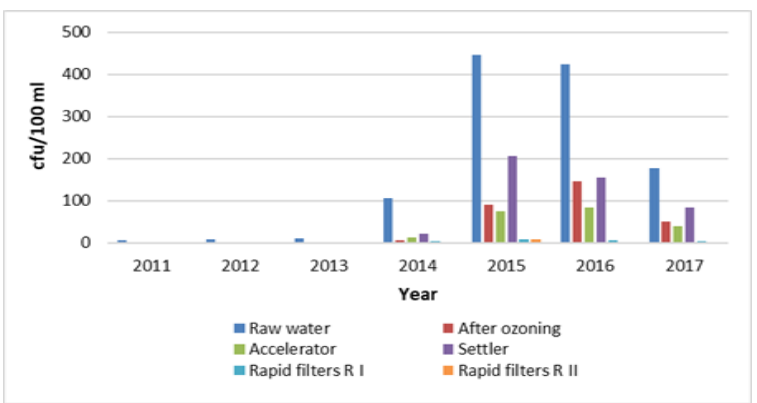

3a.

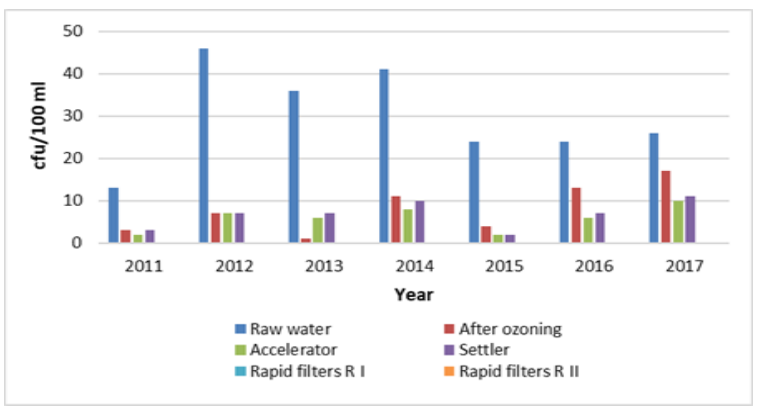

$3 b$.

Fig. 3. Changes in the amount of microorganisms after individual stages of water treatment at "Raba" Water Treatment Plant during 2011-2017: 3a. Coli bacteria; 3b. Clostridium perfringens. Source: own research based on MPWiK's results

\subsection{Physicochemical indicators}

This paper presents relationships between raw and treated water as related to the following quality indicators: colour, turbidity, ammoniacal nitrogen, nitrates (III), nitrates (V), phosphates (V), chlorides, sulphates (VI), total organic carbon (TOC), permanganate index (oxidability) and total hardness (Figures 4a-41). Annual means of individual parameters and the degree of their removal from surface water drawn from Dobczyce Reservoir were calculated for a seven-year research period.

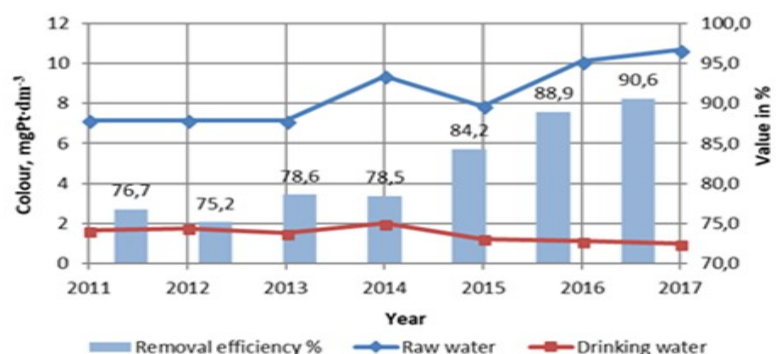

4a.

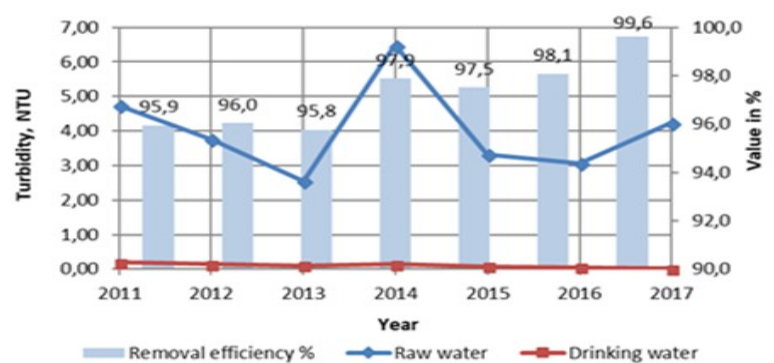

$4 b$.

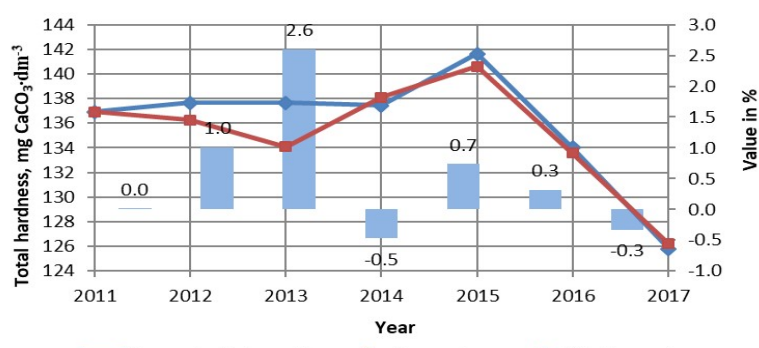

Removal efficiency \% $\rightarrow$ Raw water $\rightarrow$ Drinking water

$4 c$.

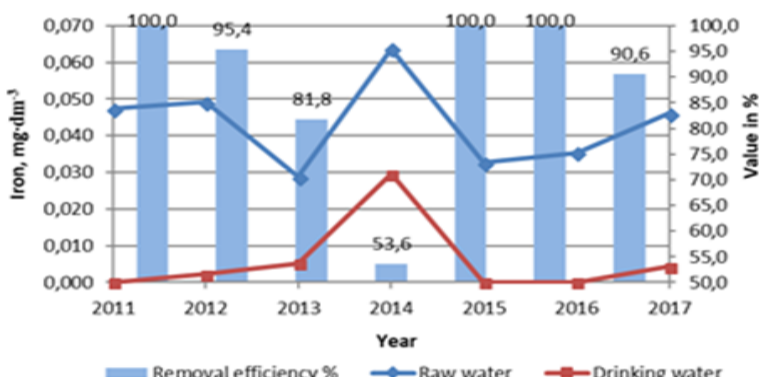

4d. 


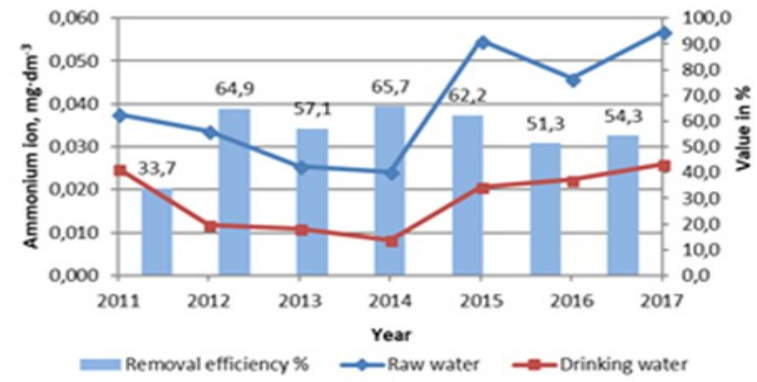

4e.

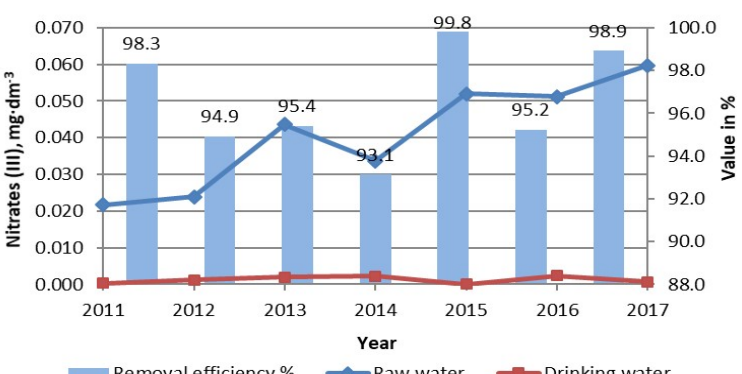

$4 f$.

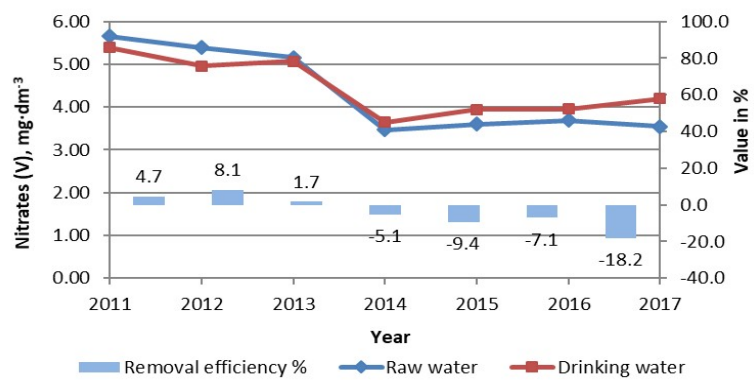

$4 g$.

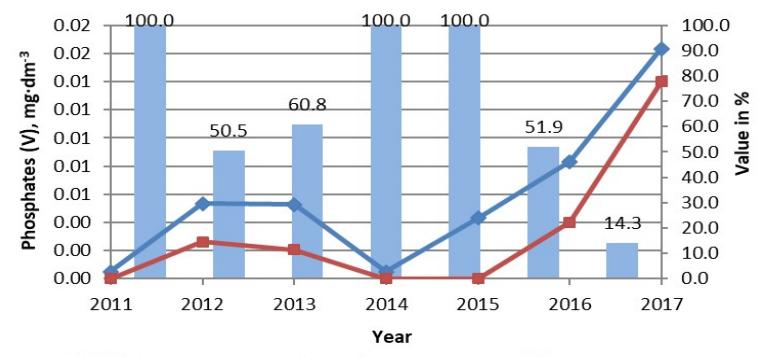

Removal efficiency \% $\rightarrow$ Raw water $\rightarrow$ Drinking water

4h.

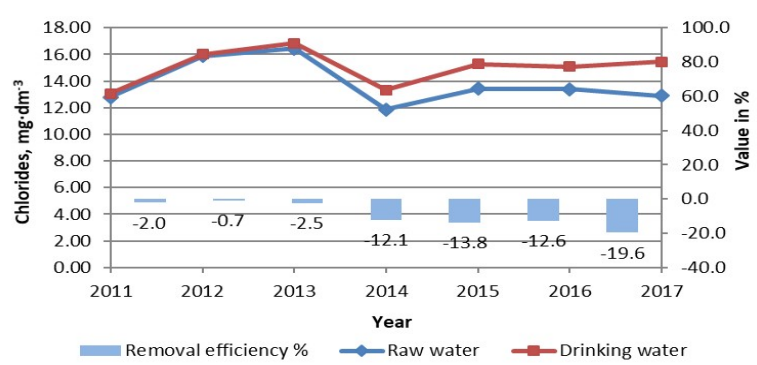

$4 i$.

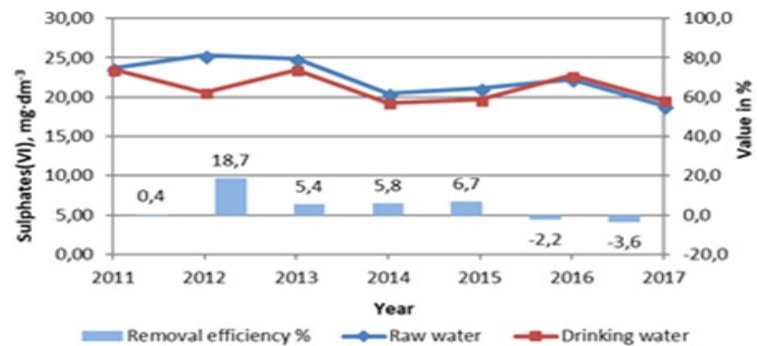

4j.

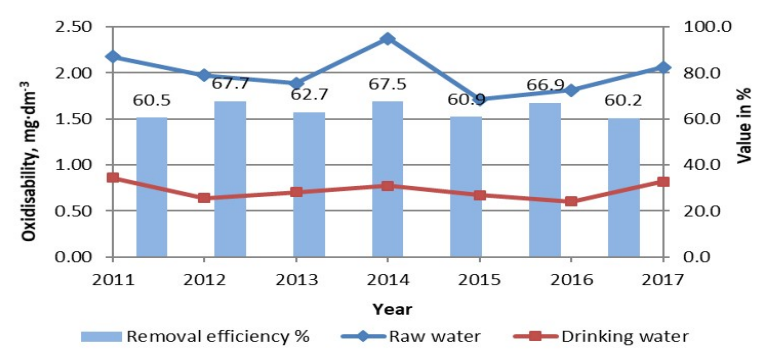

$4 k$.

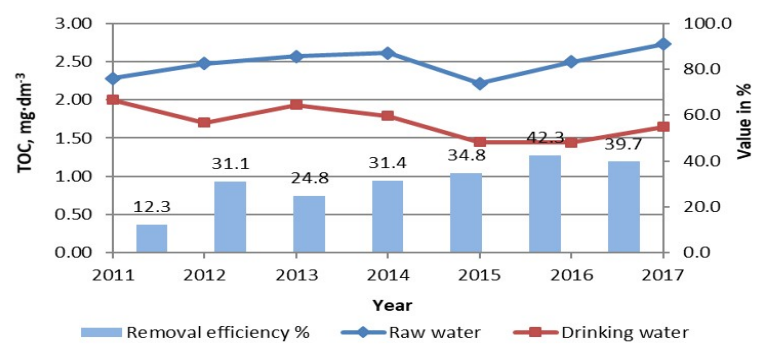

41.

Fig.4. Changes in mean annual physicochemical indicators in raw and drinking water during 2011-2017: 4a. Colour; 4b. Turbidity; 4c. Total hardness; 4d. Iron; 4e. Ammonium ion; 4f. Nitrates (III); 4g. Nitrates (V); 4h. Phosphates (V); 4i. Chlorides; 4j. Sulphates (VI), 4k. Oxidabilty; 4l. TOC

Source: own research based on MPWiK's results

In the tested water, the highest degree of removal of pollutants was observed in the case of the following indicators: manganese $-100 \%$, nitrates (III) $(93.1 \%-$ $99.8 \%)$, turbidity $(95.8 \%-99.5 \%)$, colour $(75.2 \%-$ $90.6 \%)$, total iron $(53.0 \%-100.0 \%)$ and ammonium ion $(33.7 \%-65.7 \%)$.

Employment of the coagulation process combined with the separation of the solid phase efficiently eliminates colloidal substances and suspensions (for which it is difficult to settle on the bottom) causing turbidity and colouring [18-19]. Many years of research show that aeration is an effective method of removal of otal iron and manganese, involving oxidation of these compounds by means of oxygen from the air [20]. Precipitated salts are then separated by means of classic solid phase separation methods. Aeration is also employed for removal of some pollutants giving water unpleasant taste and smell as well as a number of volatile organic micro-pollutants and radioactive radon. It is also worth stressing that drinking water in the analysed period met the applicable standards in terms of taste and smell, being acceptable for consumers. This fact 
confirmed the efficiency of individual processes used in the investigated plant. The efficiency of removal of ammoniacal nitrogen and nitrates (III) is affected by the ability of microorganisms present on filters to biodegrade them, which was characterised in detail in the introduction. This process involves biochemical oxidation of ammoniacal nitrogen to nitrate nitrogen which then undergoes reduction to molecular nitrogen or nitrogen oxides. On the other hand, nitrates (III), depending on conditions where the water treatment process takes place, can undergo oxidation to nitrates (V) or reduction to nitrogen (II) oxide and nitrogen (I) oxide [21]. In addition to biological assimilation, the efficiency of removal of ammonium ions is also affected by adsorption on the surface of solid particles being removed by means of physical methods [22]. It has been proven that the use of activated carbons is an effective method of elimination of these pollutants from water [23].

One of the factors, which can affect development of a suitable bed for the process of nitrification, is the use of beds with high internal porosity. These include activated carbon used at "Raba" Water Treatment Plant and chalcedonite bed. Chalcedonite is used in classic systems of combined removal of iron, manganese and ammonium nitrogen from water. Analysing the obtained results, it should also be emphasised that conventional water treatment systems are characterised by a lack of individual processes that would make it possible to efficiently remove all nitrogen compounds by means of biological assimilation or oxidation [22].

In the investigated water treatment process, clear removal of phosphates (V) was observed whereby the efficiency of elimination ranged from $14.3 \%$ to $100.0 \%$. Efficient removal of phosphate ions is affected by their coprecipitation in the form of sparingly soluble compounds in the process of coagulation [24-25]. The degree of reduction of content of phosphates is also impacted by their low concentration in raw water.

Compared to surface water, treated water was found to have larger quantities of nitrates (V) and chlorides. An increase in the concentration of nitrates $(\mathrm{V})$ in treated water ranged from $5.1 \%$ to $18.2 \%$ in the examined period. It has been proven that feeding water containing significant quantities of biogenic compounds into a water supply network is unfavourable due to loss of stability, formation of biological sediments in pipes and deteriorating organoleptic properties of water. Currently, there are a few methods for removal of nitrates from drinking water. Conventional processes employed in water treatment (such as coagulation, filtration, chlorination, UV radiation and ozonation) do not produce the desired effect in the process of removal of nitrates from water. That is why other elimination techniques are used, including ion exchange, reverse osmosis, biological denitrification and chemical reduction. In addition to nitrates, sulphates are also removed from purified water in the process of ion exchange while much greater capabilities of separation and concentration of components found in water are achieved without interference into their molecular structure in reverse osmosis. These processes encounter numerous limitations in their use due to costs and the problem of management of concentrated sewage [26-27]. Biological methods are an alternative solution to the above ones, reducing the total cost of purification. In addition, they considerably simplify water treatment process systems [26].

Furthermore, chloride concentrations in water after the purification process increased in the range from $2.0 \%$ to $19.6 \%$ compared to raw water. This could have been affected by the type of coagulant used in the treatment process - PAX 16 (polyaluminium chloride) [28].

The conducted research shows that the treatment methods used at "Raba" Water treatment Plant remove total hardness to a small extent. The average efficiency of elimination of this indicator over the seven-year research period is only $0.83 \%$. In the case of excessive water hardness, several precipitation methods are used [29] that can be employed in conjunction with ion exchange processes [30]. On the other hand, reduction of total water mineralisation and removal of micromolecules are enabled by membrane processes [31], whereas removal of radionuclides requires use of precipitation methods, sorption on activated carbons and sometimes aeration [19].

The efficiency of removal of the total organic carbon content in all investigated types of water was in the range of $12.3-42.3 \%$. Research by Świderska-Bróż and Wolska shows that the efficiency of removal of an organic substance from water is determined by processes of coagulation and filtration through biologically active beds [32].

In contrast, organic compounds measured by the oxygen index expressed as oxidability are removed from water to a slightly greater extent $(60.2 \%-71.0 \%)$. What follows from the above is that the values of the permanganate index and total organic carbon in surface water are affected by the degree of pollution of raw water and the time of flow of water through biologically active beds.

Table 2. Mean values of raw and drinking water quality indicators and efficiency of their removal in 2011-2017.

\begin{tabular}{|c|c|c|c|c|c|c|}
\hline \multirow{3}{*}{ Indicator } & \multirow{3}{*}{ Unit } & \multicolumn{4}{|c|}{ Water } & \multirow{3}{*}{$\begin{array}{c}\text { Removal } \\
(\%)\end{array}$} \\
\hline & & \multicolumn{2}{|c|}{$\overline{\text { Raw }}$} & \multicolumn{2}{|c|}{ Drinking } & \\
\hline & & Mean & Max & Mean & Max & \\
\hline Colour & $\mathrm{mgPt} \mathrm{dm^{-3 }}$ & 8.00 & 30.00 & 1.49 & 12.00 & 81.34 \\
\hline Turbidity & NTU & 4.00 & 125.00 & 0.11 & 3.90 & 97.30 \\
\hline Iron & \multirow{9}{*}{$\mathrm{mg} \cdot \mathrm{dm}^{-3}$} & 0.04 & 1.08 & 0.01 & 0.62 & 74.57 \\
\hline Ammonium ion & & 0.04 & 0.44 & 0.02 & 0.22 & 56.24 \\
\hline Nitrates (III) & & 0.04 & 0.18 & 0.00 & 0.05 & 96.75 \\
\hline Nitrates (V) & & 4.35 & 20.17 & 4.45 & 17.00 & -2.18 \\
\hline Phosphates (V) & & 0.01 & 0.13 & 0.00 & 0.07 & $\overline{36.36}$ \\
\hline Chlorides & & 13.82 & 23.95 & 15.00 & 40.00 & -8.53 \\
\hline Sulphates (VI) & & 22.66 & 36.00 & 20.94 & 32.60 & 7.57 \\
\hline TOC & & 2.47 & 4.46 & 1.69 & 3.25 & 31.54 \\
\hline Oxidability & & 2.07 & 3.20 & 0.75 & 1.30 & 63.77 \\
\hline Total hardness & $\mathrm{mg} \mathrm{CaCO} \cdot \mathrm{dm}^{-3}$ & 136.00 & 161.00 & 134.87 & 159.00 & 0.83 \\
\hline
\end{tabular}

Source: own research based on MPWiK's results

Oxidants most frequently used in water treatment processes include: air, chlorine, ozone and chlorine (IV) oxide. What is used in water treatment plants are very 
reactive oxidants that transform the organic matter found in water. Biodegradable organic matter (BOM) is formed as a result of a breakdown of molecules with high molecular weight and action of oxidants. It can contribute to bacterial growth in the water distribution system [33].

Table 2 shows descriptive statistics of individual indicators in water before the treatment process and after the treatment as well as their degree of removal from raw water over the seven-year research period.

\section{Conclusions}

1. The use of the coagulation process combined with the separation of the solid phase efficiently eliminates colloidal substances and suspensions (for which it is difficult to settle on the bottom) causing turbidity and colouring.

2. A properly conducted filtration process preceded by continuous coagulation enables removal of bacteriological pollutants to a high extent.

3. At "Raba" Water Treatment Plant, when using existing protective barriers, UV radiation was used as an additional barrier to eliminate bacteria of the Clostridium genus, protozoa and viruses.

4. None of the individual processes in the conventional water treatment process ensure combined efficient elimination of all biogenic components.

5. Out of inorganic nitrogen compounds, ammonium ions are efficiently removed, but they make up a small portion of inorganic nitrogen.

6. An individual process ensuring the most efficient elimination of ammonium ions and phosphates (V) from treated water in the examined process system was coagulation.

7. The efficiency of elimination of total organic carbon and biogenic compounds in the water treatment process is influenced by their content before the process.

8. No type of water fed into a water supply network provides total protection against secondary growth of microorganisms with respect to inorganic nitrogen compounds.

\section{Acknowledgements}

Publication supported by the Polish Ministry of Science and Higher Education as a part of the program of activities disseminating science from the project ,Organization of the First International Science Conference - Ecological and Environmental Engineering”, 26-29 June 2018, Kraków.

\section{References}

1. A. L. Kowal, M. Świderska-Bróż, Purification of water. Theoretical basis and technological processes and equipment (Warsaw: PWN, 2009)
2. MPWiK, Characteristics of water treatment technology in the Water Treatment Plant in Raba, Cracow (2014)

3. W. Adamczyk, A. Jachimowski, An effect of the Treatment Process on Drinking, Water Quality in Cracow, [in:] J. Szakiel, J. (ed.) Commodity science in the age of globalization, Polish Society of Commodity Science, Cracow, 7-19 (2014)

4. MPWiK (2018). Results of laboratory analyzes of drinking water and tap water quality indicators for ZUW Raba, made at the Central Laboratory in 2011-2017, Own study, Cracow (2018)

5. MPWiK, Register of research methods, Central Laboratory MPWiK. Cracow (2013)

6. W. Hermanowicz, J. Dojlido, W. Dożańska, B. Koziorowski, J. Zerbe, Physical and chemical testing of water and sewage (Warsaw: Arkady, 1999)

7. H. Elbanowska, J. Zerbe, J. Siepak, Physicochemical examination of waters (Poznań: UAM, 1999)

8. A. Cygański, Chemical methods of quantitative analysis (Warsaw: WNT, 2012)

9. J. R. Dojlido, J. Zerbe, Instrumental methods of testing water and wastewater, (Warsaw: Arkady, 1997)

10. J. Siepak (ed.), Applications of ion chromatography in water analysis (Poznań: UAM, 1999)

11. R. Michalski (ed.), Ion chromatography modern method of determination of anion and cations in the water and wastewater (Zabrze: Instytut Podstaw Inżynierii Środowiska PAN, 2007)

12. R. Michalski (ed.), The use of ion chromatography in environmental analytics (Zabrze: Instytut Podstaw Inżynierii Środowiska PAN, 2008)

13. R. Michalski, Ion Chromatography (Warsaw: WNT, 2015)

14. M. Modelska, S. Buczyński, Prz. Geol., 55, 4, 319 323 (2007)

15. A. Jachimowski, Inż. Ekolog., 18, 1, 118-125 (2017)

16. W. Balcerzak, Eutrophication of stagnant water forecasting and impact on water treatment technology, (Kraków: Wydawnictwo PK, 2009)

17. P. Payment, A, Locas, Ground Water, 49, 1, 4-11 (2011)

18. T. Nkurunziza, J. B. Nduwayezu, E. N. Banadda, I. Nhapi, Wa. Sci Technol., 59, 8, 1551-1558 (2009)

19. S. Biłozor, J. Nawrocki, U. Raczyk-Stanisławiak, J. Świetlik, Characteristics of natural water quality, [in:] J. Nawrocki (ed.) Water treatment. Physical, chemical and biological processes. Part I, (Warsaw: PWN, 2010)

20. J. Nawrocki, S. Biłozor, W. Ilecki, B. KasprzykHordern, Oxidation in water treatment technology, [in:] J. Nawrocki (ed.) Water treatment. Physical, 
chemical and biological processes. Part I, (Warsaw: PWN, 2010)

21. D. Papciak, J. Zamorska, L. Kiedryńska, Microbiology and biotechnology in water treatment processes (Rzeszów: Oficyna Wydawnicza Politechniki Rzeszowskiej, 2011)

22. M. Wolska, Removal of biogenic substances in the treatment technology of water intended for human consumption (Wrocław: Oficyna Wydawnicza Politechniki Wrocławskiej, 2015)

23. E. Okoniewska, Inż. Ochr. Śr., 3, 3/4, 487-490 (2000)

24. K. Jóźwiakowski, Inż. Rol., 10, 5(80), 249-256 (2006)

25. J. Malej, A. Majewska, A. Boguski, Rocz. Ochr. Śr., 4, 11-48 (2002)

26. K. Żeglin-Kurbiel, W. Wójcik, Gaz Woda, 9, 28-32 (2007)

27. W. L. Ang, A. W. Mohammad, N. Hilal, C. P. Leo, Desalination, 363, 2-18 (2015)
28. M. Yan, D. Wang, J. Yu, J. Ni, M. Edwards, J. Qu, Chemosphere, 71, 9, 1665-1673 (2008)

29. J. Nawrocki, S. Biłozor, Coagulation and precipitation, [in:] J. Nawrocki (ed.) Water treatment. Physical, chemical and biological processes. Part I, (Warsaw: PWN, 2010)

30. U. Raczyk-Stanisławiak, J. Nawrocki, J. Świetlik, Ion exchange, [in:] J. Nawrocki (ed.) Water treatment. Physical, chemical and biological processes. Part II, (Warsaw: PWN, 2010)

31. S. Mozia, J. Przepiórski, A. W. Morawski, Membrane processes in water treatment, [in:] J. Nawrocki (ed.) Water treatment. Physical, chemical and biological processes. Part II, (Warsaw: PWN, 2010)

32. M. Świderska-Bróż, M. Wolska, Ochr. Śr., 33, 1, 912. (2011)

33. A. Matilainen, M. Vepsäläinen, M. Sillanpää, Adv. Colloid Interface Sci., 159, 2, 189-197 (2010) 